\title{
Field Theory and Interdisciplinarity: History and Sociology in Germany and France during the Twentieth Century
}

\author{
GEORGE STEINMETZ \\ Sociology, University of Michigan
}

\section{ACTIVITY AT THE BORDERLANDS OF DISCIPLINES}

This article proposes an original theory of interdisciplinarity and a revisionist history of interactions between the sociology and history disciplines. It examines relations between historians and sociologists in Germany and France over the course of the twentieth century, focusing on several key moments of interdisciplinary activity.

The present article differs from the existing literatures on historical sociology and interdisciplinarity in several ways. Most accounts of historical sociology since the 1980s have depicted an endeavor taking place entirely within sociology, occluding other axes of interdisciplinarity. Rather than focusing on sociologists working historically, or historians working sociologically, I begin by reconstructing both of the disciplinary fields within the metafield of academic disciplines. I then consider the full range of interactions and practices coming from both directions. According to most previous accounts, disciplines evolve as unified totalities, generations, or waves. I analyze disciplines as social fields - as dynamic, relational, and internally heterogeneous and divided assemblages. Rather than asking how entire disciplines interact with one another, I focus on the ways specific actors and groups within disciplines relate to specific parts of external disciplines. I try to map the entire array of interactions and repulsions between disciplines. Rather than simply describing interdisciplinary practices, I ask how these practices have been supported or hindered by causal forces located within disciplines and at varying distances

Acknowledgements: I am grateful to Julia Hell, Phil Gorski, Howard Brick, participants in the symposium on "The Sociology of the Social Sciences 1945-2010" at the University of Copenhagen, 9-11 June 2011, and several anonymous CSSH reviewers for comments on earlier versions of this paper. 
from the central loci of knowledge production. I will show how interdisciplinary engagements are rooted in scientific problems and puzzles, field-specific interests and battles, and pressures and inducements coming from states, businesses, foundations, and scientific/educational administrators.

There are several additional shortcomings of the extant literature. Most accounts of historical sociology have focused on the United States (Smith 1991; Adams, Clemens, and Orloff 2005) and to a lesser extent the UK (Hall 1989). I will argue that historians and sociologists have interacted more intensively and over a longer period of time in France and Germany. Earlier accounts of historical sociology have been Whiggish, seeing historical sociology as progressing scientifically and gradually becoming a professional specialization within sociology, or as a succession of all-encompassing generations or waves. ${ }^{1}$ The present account examines both disciplines and their full array of strategies, programs, and practices vis-à-vis one another, rather than picking out one strand of interactions or a single privileged scientific path.

I will also argue against any suggestion that interdisciplinarity is an inherent good. It is a commonplace that scientific discoveries emerge at the frontiers between disciplines and that the current array of social science disciplines does not map onto distinct regions, boundaries, entities, or ontologies in the real world (Francis 1951; Gulbenkian Commission 1997). It is widely acknowledged that the rigid embrace of a single discipline can stunt scholarly imaginations (Roche 1986). The word discipline, since Foucault, is inextricably linked to ideas of external domination and power. Yet not all forms of interdisciplinarity are equally fruitful. Some features of disciplinarity (if not disciplines themselves, as currently configured) are necessary for social scientific creativity.

More specifically, I ask which forms of interdisciplinarity have been most conducive to intellectual flourishing, defined here as the creation of good new ideas in the social and human sciences. ${ }^{2}$ I avoid the word innovation, associated with corporate orientations, and creativity, which tends to be associated with sociobiology and other ideologies of elite domination. The words flourishing and fruitfulness, as used here, are not limited to scientific truthfulness but may also encompass ethical and aesthetic dimensions.

The most fruitful forms of interdisciplinarity between history and sociology, I will argue, were the interactions between Annales historians and sociologists in the interwar period, and those involving Bourdieu, Bourdieusian

\footnotetext{
${ }^{1}$ For the "waves" model, see the introduction to Adams, Clemens, and Orloff 2005. Also inadequate are depictions of social science as consisting of multiple "theory groups" (Mullins 1973) or as an entirely agonistic Kampfplatz (Abbott 1999).

${ }^{2}$ Intellectual, artistic, and scientific work has to be included in any valid project of human flourishing, as recognized by Marx (1970) and Wright (2012); see Steinmetz 2015. On judgmental rationalism in the selection of theory and the role of the imagination (particularly analogical imagination) in retroductive reasoning, see Bhaskar 1986, and Peirce 1931.
} 
sociologists, and some French historians since 1980. These projects entailed a turn to a neo-historicist epistemology in which singular events and processes became legitimate objects of social science and were explained in terms of unique and contingent conjunctures of theoretically defined causes. ${ }^{3}$

The generativeness of these knowledge collectives also stemmed from their dialogism and their relative autonomy. I illustrate the interaction between these two features using the example of Nazi-era interactions between historians and sociologists. On the surface, this was an exemplary case of interdisciplinarity, a processual configuration characterized by relative equality between the two disciplines. It generated new forms of knowledge, including the idea and practice of social history itself, in its modern (German) form. But while this intellectual space was able to produce novel research practices and to shift historians' focus from social elites to the dominated masses, its language, politics, and conceptual framework were perverted by the participants' semi-voluntary obeisance to Nazi ideology. Without autonomy, interdisciplinary processes cannot reach their potential. ${ }^{4}$

The best interdisciplinary processes emerge from interactions of a specific sort. They connect individuals and positions that have relatively equal power or weight within their respective disciplinary fields. These interactions are processual, dialogic, recursive, and open-ended, leading to the interpenetration of disciplines. They are motivated by intellectual problems and field-specific conflicts, not by external cajoling or compulsion. Less fruitful forms of interdisciplinarity have the following features: they are externally induced, one-sided, or organized around a division of labor that reasserts disciplinary difference rather than allowing a fusion of perspectives.

The existing literature on social science interdisciplinarity tends to be prescriptive and bureaucratic. The present article suggests that the most productive interdisciplinary conjunctures have resulted from serendipitous resonances and contingent interactions. It would therefore be difficult, if not impossible, to produce desirable interdisciplinary processes intentionally, even if we can explain their emergence retroactively. Nonetheless, the present analysis points to several necessary if not sufficient conditions for utopian forms of interdisciplinarity. One of these preconditions, paradoxically, is the strong defense of disciplinary autonomy, or more precisely, the defense of semi-autonomous fields of knowledge production.

Two features of history and sociology make them ideally suited for a study of interdisciplinarity. History may be an older word and practice than sociology, but a substantial corps of fulltime professional historians has not existed for

${ }^{3}$ I defend the neo-historicist epistemology associated with interwar German GeschichtsSoziologie, the interwar Annales School, and the mature Bourdieu, in Steinmetz 1998; 2005; and 2010b.

4 While Nazism is perhaps an extreme example, similarly constrained forms of interdisciplinarity result from corporate control (Taylor 2016) and from top-town programs designed by university administrators (Jacobs and Frickel 2009; Jacobs 2013). 
much longer than sociology (Salomon-Delatour 1962: 602). The two academic fields are about the same age. The relative power of the two disciplines within their national scientific and academic fields has varied enormously but has not always tipped in the same direction. History obtained professorial positions, dedicated university degrees, and professional organizations before sociology, and it has usually been a larger discipline. Yet sociology loomed, threatening to overwhelm history in terms of scientific power and dynamism at several moments, including during the decades before World War I in France and the post-World War II era in Europe and the United States. Relative equality of the interacting parties seems to be a precondition for fruitful crossdisciplinary interaction. More precisely, the relevant subdisciplines should have relatively equal status within their own disciplines, and should be on a similar trajectory. Situations in which one discipline or subdiscipline is ascendant and the other stagnant or declining are less conducive to genuine interaction. ${ }^{5}$

Another distinctive feature of the history-sociology relation is that both disciplines developed analytic approaches to the problem under investigation here. Sociology's interest in intellectuals and science began with the Wissenssoziologie (sociology of knowledge) of Scheler and Mannheim, continuing through Bourdieu. As Collini (1985) notes, Mannheim's Wissenssoziologie was the first "method or theory or set of concepts" used by intellectual historians. On closer examination we find that Mannheim's historicist sociology was itself rooted in nineteenth-century historicism - a product of historians. Intellectual history and the sociology of knowledge are inextricably connected.

Several questions guide this article: What are the main forms of interdisciplinarity? Which sorts of interdisciplinarity are best suited to social scientific flourishing? I examine patterns of disciplinary contact, avoidance, and exchange, attentive to the intellectual admixtures that sometimes arise from such interactions. I identify three main axes of variation within interdisciplinary practices: (1) Symmetry, or equal participation by the parties, versus asymmetry; (2) processual orientations, versus an orientation toward discrete outputs; (3) autonomy, versus heteronomy. The first two features are often linked. Symmetry is a precondition for more processual, dialogic interactions in which disciplines interpenetrate and learn from one other. Product-oriented formats usually involve a disciplinary division of labor in which the outputs of different disciplines are presented discretely and side by side.

I also ask about the determinants of more symmetrical forms of interdisciplinarity. What accounts for changes in general levels of enthusiasm for interdisciplinarity? Why are different sectors of a given academic field associated

\footnotetext{
${ }^{5}$ Elsewhere I explore the effects of a reversal of disciplinary fortune between British and French sociology and anthropology/ethnology during the 1950s leading anthropologists to draw sharper boundaries against sociology (Steinmetz 2013).
} 
with different interdisciplinary styles, strategies, and targets? Here I am especially interested in the intellectual and strategic interests at play in divergent views of interdisciplinarity. Interests are defined here as goals defined and pursued within a specific field, for symbolic or material gain, or for their own sake. Interests are thus irreducible to economic or political interests or any of the other "interests specific to other fields" (Bourdieu 1993: 72). Actors located in different sectors of a given disciplinary field usually have different interests relating to disciplinarity. Some of these interests derive from structural positions in the field and are oriented primarily toward its competitive dynamics (Bourdieu 1991). Other interests stem from irreducibly scientific problems, ethical quandaries, or aesthetic judgments.

Interdisciplinarity is driven by three main sorts of motives, involving (1) questions that push scholars out of their own disciplines, (2) battles within a given discipline, and (3) conformity with internal or external authorities.

In order to shed light on these issues, I examine five contexts in which German and French historians and sociologists interacted intensively during the twentieth century. Dialogic, processual, scientifically autonomous forms of interdisciplinarity emerged in two specific contexts. The first involved the interwar Annales School and neo-Durkheim sociologists; the second involves a group of sociologists and historians around Pierre Bourdieu and his work, since the 1980s. An intermediate type of interdisciplinarity is represented by German Geschichts-Soziologie (history-sociology) during the Weimar Republic. Here sociology opened itself up to interpenetration by history, but without much reciprocal interest from the latter (Welskopp 2005). The fourth case, West German Historische Sozialwissenschaft (historical social science) in the 1970s and 1980s, also represents a one-sided form of interdisciplinarity, a version of sociological history without sociologists. ${ }^{6}$ The fifth case involved heteronomous interdisciplinarity: Nazi-era German Volksgeschichte (ethnic or folk history) and its successor, post-1945 West German Strukturgeschichte (structural history). The autonomy of scientific disciplines was severely eroded in Nazi Germany. Yet Volksgeschichte and Strukturgeschichte were also partly generated from the bottom up, within the history and sociology disciplines. And they did represent a dialogic, processual form of interdisciplinarity in which the two parties were relatively equal in power and evolved methodologically and analytically over time. This example demonstrates once again that epistemology cannot be reduced to politics and that it is misleading to speak of an epistemological Left and Right (pace Novick 1988).

\footnotetext{
${ }^{6}$ Elsewhere (2005) I have discussed an extremely unidirectional formation, American "historical sociology" in the 1920s-1930s and 1980s-1990s. This formation was located almost entirely within sociology.
} 
The first part of the article presents a theoretical approach to the historical analysis of disciplines grounded in Bourdieu's mature social theory. ${ }^{7}$ The second section looks more closely at interactions between history and sociology in Germany and France during the twentieth century.

\section{II.FIELD THEORY AND THE STUDY OF DISCIPLINES AND}

IN T E R D I S C I P L IN A R I T Y

Bourdieu's field theory sensitizes us to the creation and breakdown of disciplinary boundaries and the determinants and patterns of repulsion and interaction across disciplines. A scientific field, according to Bourdieu, is a social microcosm that is "partially autonomous from the necessities of the larger social macrocosm that encompasses it" and "endowed with its own laws of functioning" (1991: 375). Fields are not static and must be analyzed historically. Fields can be examined with respect to their genesis, consolidation and settling, re-foundation, destabilization, annexation and loss of sovereignty, and outright disappearance, and sometimes their resurrection and reconstitution.

Fields are usually governed by competition for a single species of symbolic capital - a field-specific currency of distinction-over an extended period of time. But fields may also undergo "specific revolutions" that transform the species of symbolic capital around which conflict is primarily organized. Fields also experience less drastic transformations. Within more settled fields there is a hegemonic definition of what counts as valuable symbolic capital, one that is agreed upon even by those who are disadvantaged by it. In more unsettled fields there is disagreement about what counts as distinction - an "anomie of competing principles of legitimation" (ibid.: 380).

The architecture of most fields is defined by two principal axes, though there may be additional ones (Wang 2016). The cardinal axis indexes the particular resource around which competition is organized. Inequality within a field is defined primarily by differences along this dimension. (Realms of practice that are not permeated by inequality cannot be fields in Bourdieu's sense, by definition.) The field's second axis runs from autonomy to heteronomy. This axis is equally important, because fields are defined by their relative autonomy from other fields and from concentrations of social power such as the state, the economy, and the mass media. When the field in question is a scientific discipline, differences in independence from the outside world will be connected to differing interests in interdisciplinarity. Although a field's boundaries are partially permeable, its autonomy depends on border controls that regulate the entrance and exit of people and ideas. Such border controls clearly play an important role in most forms of interdisciplinarity.

\footnotetext{
${ }^{7}$ The explanatory power of Bourdieu's field theory is suggested by his own studies (see bibliography) and many others; see Charle and Ferré 1985; Heilbron 2015; Lenoir 1997, Raphael 1994; and Gorski 2013.
} 
Autonomy is the sine qua non for scientific knowledge, which requires judgmental rationality to govern adjudication among alternative theoretical accounts (Bhaskar 1997 [1975]: 1986). Autonomy may also be a precondition for inventiveness in general (Bourdieu 2013). More fielded disciplines evolve at their own pace, with new problems and questions being generated by internal discussions and dynamics. Autonomy in the context of knowledge fields defines a central dimension of scientific freedom. Philosophers have argued since Kant that "social institutions ... represent the objective moment which is necessary to realize freedom in its subjective, moral form" (Rössler 2013). Applied to science, this suggests the need for positive as well as negative freedom-freedom from scientific constraint and positive freedom in the guise of resources and recognition. Indeed, recognition of all other field participants by each member is an intrinsic assumption of Bourdieusian field theory and a necessary complement to fields' inherent agonism (Steinmetz 2013). This suggests that the existence of bounded, self-governed fields of practice may be indispensable for science, even if extant divisions of disciplinary labor are arbitrary and artificial from the standpoint of social ontology.

Scientific heteronomy, by contrast, is a situation in which scientific practices are oriented mainly toward actors and ideas outside the home fieldtoward government and private funding agencies, sponsors, clients, censors, and the media. Larger institutions sometimes shape the hierarchy and ontological division of labor among disciplines, or create entirely new disciplines and forms of interdisciplinarity. When members of a discipline cannot resist the pull of an adjacent discipline or of external powers, interdisciplinarity is impoverished.

Of course, there may be other axes of power within disciplinary fields, which need to be discovered empirically. Moreover, the same resource (or species of "capital") may operate differently in each discipline, according to rules specific to that discipline (Gingras 2014: 279).

This points to another key concept: habitus. There is no need to recapitulate the evolution of the habitus concept in Bourdieu's thinking, which others have discussed in great detail, but we do need to emphasize that field-like social structures and institutions do not exist separately from the practices that conjure them into existence and reproduce them (or not). Bhaskar refers to this as the "activity-dependent nature of social structures" (1979: 63). Habitus is both a product and a producer of social fields. Put differently, an individual habitus preexists any given field biographically and continues to co-determine the field, while being remolded by that same field over time. Habitus and field are connected dialogically, in a process without a telos. ${ }^{8}$

\footnotetext{
${ }^{8}$ The absence of field-level goals is one of the salient differences between Bourdieusian field theory and Fligstein and McAdam's (2012) "strategic field theory," which defines fields as focused on "cooperative" action by participants and elides the difference between social fields
} 
Once we have defined the main features of a field, including its specific form of symbolic capital, the coordinates according to which autonomy and heteronomy are defined, and the field-specific habitus and rules of practice, then we can begin to identify the positions that structure the field in question and to analyze the interdisciplinary interests associated with different positions. As an example, consider contemporary American sociology. Scholars located in the dominant and autonomous quadrant of sociology tend to seek academic allies in disciplines with high prestige in the overarching American scientific field, like economics and the natural sciences. Scholars in sociology's dominated and autonomous quadrant typically seek out connections with structurally analogous locations in other disciplines or with autonomous disciplines that are relatively dominated within the overarching scientific field (history, cultural and social anthropology, continental philosophy, etc.). Scholars in sociology's dominant and heteronomous quadrant are pulled toward the field of power, and seek alliances with applied, practical, or politicized disciplines and professional schools, government and military agencies, think tanks and foundations, corporate actors, and the media (Bourdieu 1998). Sociologists in the dominated and heteronomous quadrant, finally, gravitate toward popular social movements and the critical public sphere. Of course individuals can migrate among positions within a given field (Bourdieu 1996) or participate in more than a single field.

The style of rapprochement with external disciplines also tends to differ depending on the structural location in the home discipline. Scholars in heteronomous positions are pulled into the orbit of external agendas. Autonomous scholars move toward other disciplines in a more autonomous manner, seeking contacts relevant to their scientific interests or useful in struggles within the home field. This usually leads to a controlled importation of "foreign" ideas, although there may also be lengthier forays into foreign disciplinary lands. In unusual cases a third social space between disciplines is constituted, which may eventually become partially autonomous and constitute itself as a new field. ${ }^{9}$

Subfields are another crucial concept in discussions of disciplinary separation and interaction. A subfield is not just a smaller discipline or a microfield, and it is not necessarily the same thing as a sector, pole, or quadrant within a field. All of a subfield's participants also participate in the environing field. They all pass through the same gate-keeping controls as everyone else in

and organizations, whose basic unit (in organizational sociology) is the firm. Most social fields lack any meta-goal, even if all of the participants in a given field are engaged in the same activity. Fields are not analogous to firms.

9 The constitution of a third space is not an automatic or autonomic process, however, as in general theories of the genesis of interdisciplines (e.g., Frickel and Ilhan 2016). 
the disciplines and subject themselves to the same credentialing routines, seeking recognition from other members of the discipline. Yet a subfield may also be distinct enough from the encompassing field to generate its own forms of symbolic capital, its own peculiar illusio, habitus, scientific libido, and competition over subfield-specific stakes. A subfield may also revise or even invert the values guiding activity in the surrounding field. ${ }^{10}$ Some subdisciplines, or disciplinary specialties, constitute subfields. Within the subdiscipline of political theory in American political science, for example, dominant disciplinary assumptions about value-freedom, normativity, regularity determinism, and the hierarchy of empirical and theoretical work are all reversed (Mihic, Engelmann, and Wingrove 2005).

A subfield, like its environing field, is typically characterized by two axes. One measures the volume of subfield-specific symbolic capital; the other indexes autonomy from external forces. The relevant outside, seen from the standpoint of a subfield, includes the environing field itself. This distinction is salient for discussions of historical sociology and sociological history. Historical sociology in the United States since the 1980s, for example, has been a well-structured subfield. At its autonomous pole, scholars tend to seek contact with historians and philosophers whose work is relevant for solving analytic problems or for fighting battles with other sociologists (including heteronomous members of the same subfield). At the subfield's heteronomous pole there is more interaction with non-historical sociologists and with the external interlocutors preferred by the dominant sector of the surrounding discipline. The heteronomous pole of historical sociology in the United States has been permeated by a neo-positivist orientation toward general covering laws and the use of comparative methods as a proxy for experiments or multivariate statistical analysis (Calhoun 1996; Sewell 1996; Steinmetz 2005). At the subfield's autonomous pole we find the use of interpretive and hermeneutic methods and historicist epistemologies that explain historical events and processes in terms of changing, unpredictable constellations of determinants and actions. ${ }^{11}$

Disciplinary fields are also grouped together into multi-disciplinary scientific metafields. The assignment of disciplines to different metafields varies cross-nationally and over time, although there has been some convergence on the American model in recent decades. A discipline's membership in a particular meta-disciplinary field promotes certain lines of interdisciplinarity and discourages others. In American universities history is often located in the humanities and sociology in the social sciences, driving a wedge between

\footnotetext{
10 This argument about subfields parallels Bourdieu's model of the literary field as a reversed economic field (1993).

${ }^{11}$ Interactions among subfields of the same academic discipline could also be analyzed using this model.
} 
these disciplines. German universities were long divided between the Geistesand Naturwissenschaften (human and natural science). The placement of sociology in the Geisteswissenschaften alongside history and the humanities gave additional force to historicist sociological approaches. In France, sociology and history both emerged as academic disciplines within the Letters Faculty of the University. That sociology was only taught in French universities as part of the philosophy Licence (Bachelor's) degree until 1958 contributed to sociology's philosophical and historical coloration.

In sum, we need to analyze the genesis, evolution, and internal organization of disciplinary fields, subfields, and metafields, and the relations among them, in order to understand patterns of disciplinary separation and interaction. We need to consider larger institutions such as universities, foundations, states, and government agencies, along with society-wide events and processes.

A final note on fields concerns their spatial specificity. Fields exist at scales larger or smaller than the nation-state (Steinmetz 2007a; 2016; 2017; Georgakakis and Vauchez 2015). Social scientists are propelled through international space by social crises, exile, and scientific careers, and these travels can cause devaluation and inflation of scientific capital and changing commitments to specific theories, epistemologies, and objects of investigation (Steinmetz 2010a). Alongside such transnational phenomena, however, social science disciplines continue to have strong national accents due to differences in intellectual traditions and educational and scientific systems (Heilbron 2008). And here again, social fields are internally divided. Groupings and individuals differ in their orientation toward the geographic exterior, and international orientations are used to fight domestic battles (Bourdieu 1991). National sociological and historical fields differ in terms of their subfields, their relative emphasis on different types of research, and perceptions of the proximity and distance among disciplines, not to mention their radically differing national histories. Because disciplines are still not organized the same way everywhere, I have organized the comments that follow around national fields.

III.RELATIONS BETWEEN ACADEMIC SOCIOLOGY AND HISTORY IN T WENTIETH-CENTURY GERMANY

To understand the relations between history and sociology we need to first step back and examine the two disciplines separately. I will then turn to patterns of cross-disciplinary friendliness and repulsion.

\section{Sociology and Sociologists}

The word Soziologie only entered the German language as a label for a certain kind of scholarship in the 1870 s and 1880 s. $^{12}$ The Verein für Sozialpolitik

12 Comte and Spencer had already been translated into German in 1875 (Dörk and Borggräfe 2015: 23). 
began sponsoring social research, including Max Weber's investigation of EastElbian immigrant agrarian workers in 1872. The German Sociological Association was founded in 1909, fourteen years after the Association of German Historians. The first sociology chairs were created in 1919. By 1933 the discipline disposed of thirty-four chairs, and there were more than one hundred sociology teachers at all levels of German universities and technical colleges (Kaesler 1984: 626-28).

Dozens of German sociologists were forced into exile after 1933 (Wittebur 1991). The sociology profession had a higher percentage of Jewish and leftwing members than did history and suffered greater proportional losses. The German Sociological Society (GSS) was dissolved in 1934, whereas the leading historians' association at the time, the Verband Deutscher Geschichtslehrer, continued throughout the Nazi era (Hasberg and Seidenfuss 2005). Most of the work done by the sociologists who remained in Germany was applied, quantitative, and presentist (Klingemann 1996; 2009). Sociology reconstituted itself slowly after 1945 . There were only five sociology professors in 1949, ten in 1953, and twenty-five in 1960 (Dörk and Borggräfe 2015: 30 n49). By 1972 there were 131 sociology Ordinarien and 631 sociologists at other ranks. In 2010, there were 320 sociology professors and junior professors in Germany (Mau and Huschka 2010: 753).

By the time sociology chairs began to be created in Germany after 1918, history was already a well-established discipline (see below). A number of German sociology's most influential founding members rallied to historicism or neo-historicism between the wars (Aron 1964 [1935]). Several scholars with history doctorates - including Alfred von Martin, Ernst Grünfeld, Carl Brinkmann, and Andreas Walther-were called to chairs in sociology. Historian Kurt Breysig obtained a chair in "Social Studies and History" (Gesellschaftslehre und allgemeine Geschichtswissenschaft) at Berlin University in 1923 (Vom Brocke 1971: 111). Neo-historicism (Beiser 2011; Troeltsch 1922) became so compelling for sociologists that Karl Mannheim, the most prominent German sociologist at the end of the 1930s, was able to argue that the "historical-individualizing" approach was the discipline's "crowning" approach, organizing its work "like an invisible hand" (1932: 9; 1952: 84). Weimar sociological neo-historicism differed from the nineteenth-century form of historicism, which refused explanation and comparison and was usually politically conservative and nationalistic (Steinmetz 2010b). According to Mannheim, sociologists had to combine the "study of singularities" (Einmaligkeitsforschung) — unique events or singular facts - with attention to causality, however complex and overdetermined, uncovering "the unique complex of determinants" (1932: 9, 10).

Mannheim's epistemological views were echoed by scholars active in Weimar sociology such as Max Scheler, Hans Freyer, Ernst Troeltsch, and various other admirers of Max Weber, who had accepted philosopher Heinrich 
Rickert's program of combining hermeneutic interpretation with causal explanation of "historical individuals" (Oakes 1987). This neo-historicist epistemology was ensconced at the Institute for the Sciences of Society and the State at Heidelberg, which was directed by Alfred Weber, Max's brother (Salomon-Delatour 1962: 628-30). Alfred Weber coined the terms "HistorySociology" (Geschichts-Soziologie) and "Cultural Sociology" (Kultursoziologie) to describe this approach.

What accounts for history's strong influence on German sociology before 1933? Why didn't Weimar sociology converge with American sociology's prevailing approach, which combined presentism, ontological empiricism, and epistemological positivism (Steinmetz 2007b)? Historicism permeated the German human sciences-including economics, cultural anthropology, law, and philosophy - to an extent found nowhere else (Iggers 1997: 36-40). And sociology's founders in Germany came from disciplines imbued with historicism - economics, philosophy, law, history, and Staatswissenschaftena combination of law, politics, and history (Lindenfeld 1997). German social scientists were acutely aware of the differences between their own historicist epistemology and what was commonly referred to as "western European" positivism (Troeltsch 1922).

The reasons for historicism's appeal were also epochal. Before 1914 historicism was linked to nationalism. The carnage of the First World War and the total political and economic crisis that followed dealt a severe blow to models of progressive social change and to the plausibility of the positivist epistemology of regularity determinism (Mannheim 1934: 13-14). German sociology responded to this societal crisis and took crisis as its basic intellectual frame to such an extent that sociology came to be described as a Krisenwissenschaft, or crisis science (Weiß 1995). This had important epistemological consequences: even diehard positivists found it difficult to claim that they could predict events like the outcome of World War I or Hitler's rise to power. The effects of crisis were not direct, however, but were mediated by existing epistemologies, as can be seen in a contrast with the United States. Since neohistoricism was weak in American sociology, the unexpected cataclysms of the twentieth century did little to temper American sociologists' belief in modernizing progress, at least until the 1960s.

Most of the German sociologists who did not go into exile or inner emigration after 1933 shifted into applied, presentist, and quantitative styles of social research (Klingemann 1996; 2009). This put an end to neo-historicism, with a few notable exceptions like Hans Freyer, who continued to promote historicism from his sociology chair at the University of Leipzig (Oberkrome 1993: 159-66; Gutberger 1996: 89-92). In 1933 Freyer was put in charge of Leipzig's Institute for Cultural and Universal History, which was "one of the largest and best-endowed institutes of historical research in Germany" (Muller 1987: 238). He moved the Institute's disciplinary center of gravity 
from history to sociology and political science (ibid.: 241). At the same time Freyer established himself as a historian, even though he had never been seen as a candidate for a history chair before 1933. In 1938, he became "the first incumbent of a new visiting professorship of German cultural history at the University of Budapest" (ibid.: 89-91). Freyer was thus perfectly positioned to mediate between the two disciplines. Although his Nazi-era activities damaged his job prospects after 1945, he retained the respect of his former colleagues and was able to take up a sociology lectureship at Münster between 1953 and 1955.

The majority of the West German sociology profession turned against neohistoricism after 1945. This epistemic shift was overdetermined by the exile of most historical sociologists in 1933, their limited reception in the United States, and the fact that only a small number of them returned to Germany after the war. The "modernization" and Americanization of the division of disciplinary labor in postwar West Germany meant that some of these re-emigrants were sorted into disciplines other than sociology (Steinmetz 2010a). An additional reason for the decline of historical sociology was the fact that any foray into the German past now required passage through the Nazi period. For the politically compromised leaders of postwar Germany sociology, shining a light on the recent past was extremely unwelcome. The president of the reconstituted GSS, Leopold von Wiese, argued in his opening speech at the first postwar sociology conference in 1948 that Nazism was a "metaphysical secret that sociology may not touch" (Von Wiese 1948: 29). Historical sociology became impracticable, unless it operated at an Olympian level, as in Freyer's European World History (1948) or Carl Schmitt's Nomos of the Earth (1950)—studies of world history that avoided discussing the immediate Nazi past except in the most euphemistic and indirect manner.

Sociological historicism was also undermined by the partial Americanization of postwar German sociology, which was a result of the U.S. occupying forces, foundations, universities, and exchange programs, and by selfappointed German modernizers. German sociologist Dietrich Rueschemeyer expressed the postwar Americanizing spirit when he dismissed Mannheim's prewar "historicist hypotheses," which he argued could not be "operationalized in a form appropriate to industrial-style research." Weimar sociology, Rueschemeyer wrote, was suited only for "essayistic work based on individual intuition."13

The memory of Geschichtssoziologie has been so thoroughly effaced even in Germany (Tenbruck 1984: 133-35) that historical sociology has become synonymous there with work carried out in the United States (Bühl 2003;

13 Kuklick (1983: 291), quoting from an unpublished paper by Rueschemeyer. In his doctoral thesis Rueschemeyer (born 1930) recommended replacing the approach of Mannheim and Scheler with small-group research (1958). 
Schützeichel 2004). According to Fischer, "Historical sociology does not have much status in Germany" and "appears only as a 'poor relation' [arme Stiefschwester] of the history discipline" (2008: 172). The GSS does not have a historical sociology section, and German sociology departments, institutes, and associations ignore historical sociology. ${ }^{14}$

\section{History and Historians}

History emerged as a "scientific discipline" in Germany during the seventeenth and eighteenth centuries (Dörk and Borggräfe 2015: 20), but in 1810 there still were only four history Ordinarien (Full Professors). Their numbers rose to thirty in 1850, ninety in 1900, and 120 in 1930 (plus thirty associate professors and lecturers). Nazism's impact was more limited than in sociology, due to the history profession's conservatism and small number of Jewish or leftwing members (Stelzel 2010: 43; Mommsen 1991: 33). Also in contrast to sociology, the history profession "survived denazification relatively unscathed," losing just 10 percent of its teaching personnel, as compared to about one third on average in all disciplines (Stelzel 2010: 43; Kater 1991: 77). A new professional organization for historians was created in West Germany in 1948, and history started being taught in the universities the following year (Schulze 1989: 24). The ranks of historians in West German universities rose from fifty Ordinarien in 1950 to around two hundred by 1960, and numbers below the rank of Ordinarius increased to 1,113 between 1960 and $1975 .^{15}$ Presently the Verband der Historiker und Historikerinnen Deutschlands has more than 2,300 members. ${ }^{16}$

While German sociologists were powerfully attracted to history before 1933, most historians vigorously rejected sociology. Historians showed "a strong tendency to denounce the Weimar system as alien to the German historical tradition" (Mommsen 1991: 32). Many rejected the very concept of society, which was associated with "chaos and disorder" and seen as opposed "to the State, in the German sense" (Salomon-Delatour 1962: 602). Historians were repelled by sociologists' tendency to refer to a plethora of "different theories," "emphasis on society and the social sphere," and indifference to the "primary role of the state" (Schleier 1975: 221). Historian Georg von Below (1919: 59) traced the popularity of the word sociology to the 1918 German Revolution, which he detested.

\footnotetext{
14 According to my perusal of German universities' course offerings and research programs in sociology (carried out in August 2015) there is no mention of historical sociology anywhere. This has been confirmed by discussions with German colleagues in the two disciplines and visits to specific universities, including Bielefeld.

15 These figures are from Conze (1977: 18-19); Mommsen (1988: 32); and Wehler (1984: 225).

${ }^{16} \mathrm{http}: / /$ www.historikertag.de/Berlin2010/index.php/historikerverband.html (accessed 2 Dec. 2016).
} 
Historians' distaste for sociology was also epistemological. Most rejected any notion of historical laws or regularities (Wahl 1925-1926), which they associated with sociology. The history elite united in opposition to the social scientific approach of Leipzig historian Karl Lamprecht (Schleier 1975: 222-23), just as British historians rejected en masse the scientific approach of T. H. Buckle (Hesketh 2011) and French historians the similar arguments of Paul Lacombe (Schulze 1974: 66; Lacombe 1894). Max Weber, who routinely aligned himself with the views of the dominant figures in each academic discipline, described Lamprecht as a "charlatan" (Whimster 1987: 282 n30).

German historians were of course not entirely uniform in their views. A few adopted a social scientific orientation, including Gustav Schmoller (1838-1917), Kurt Breysig (1866-1940), Otto Hintze (1861-1940), and Eckart Kehr (1902-1933). German social historians had a journal, Zeitschrift für Social- und Wirtschaftsgeschichte, from 1893. Yet few leading historians published there (Trüper 2005: 145-50). Social historians' "subaltern" position within the profession was expressed in the fact that most taught in economics rather than history faculties (Schulze 1974: 94).

In sum, while many German sociologists were powerfully attracted to history before 1933, most historians vigorously rejected sociology. This situation began to change during the Nazi era. Nazi science policy was strongly oriented toward interdisciplinarity (Gutberger 1996), including projects for a "new, total science" integrating history and sociology (Tendler 2013: 80-81). In history, this interdisciplinarity took the form of Volksgeschichte, which gained a solid footing at the University of Königsberg (Kaliningrad) and in an archipelago of new research institutes after 1933 (Haar and Fahlbusch 2005; Burleigh 1988; Gutberger 1996). Volksgeschichte was closely tied to Ostforschung (eastern research) and was part of a wider formation, Volksforschung or ethnic research, which permeated Nazi social science. Thus, while historicism had shaped the social and human sciences before 1933, historians were now gravitating toward an ethnic orientation that resonated with presentist, policy-oriented sociology.

Discussions of Volksgeschichte have emphasized historians' involvement in Nazi crimes (Oberkrome 1993) and the argument that West German social history - which was located politically on the left after the late $1960 \mathrm{~s}$ - grew out of a Nazi-era formation. I am more interested in the fact that Volksgeschichte stimulated historians' engagement with sociology, the one discipline that "more than any other" had been "disavowed by the classical historical profession" (Oberkrome 1995: 44, 45). Volksgeschichte shifted historians' attention away from the study of the state and high politics and moved them closer to demography, geography, comparative methods, and quantification (Klingemann 2009: 340-59; Schulze 1989: 299-300).

Yet while Volksgeschichte led to a more symmetrical and dialogic exchange with sociologists, it was clearly different from the other 
interdisciplinary formations discussed in this article. The formal features of interdisciplinarity (symmetry between the partners, dialogic processualism) are interesting not for their own sake, but ultimately because they are preconditions for more fruitful research. Nazi Volksgeschichte represents a failed and fateful interdisciplinary project, despite its processual character. Although historians like Conze were not being told exactly what to think and write by the Nazi regime, they exhibited a form of self-heteronomization that was ubiquitous in Nazi Germany. Kershaw (1993) refers to this pattern of behavior as "working toward the Führer"-anticipating what Hitler and more generally the Nazi regime would expect one to do, and doing it. In a specifically academic context, Langewiesche (1997) refers to "self-Gleichschaltung." Researchers on Stalinist societies have detected similar processes of political conformism by semi-autonomous academics (Zysiak 2015).

From the standpoint of field theory, "working toward the Führer," selfGleichschaltung, or political conformism within science amounts to selfheteronomization, a relinquishing of scientific autonomy and agency. In this respect, and not only in terms of its rebarbative politics, Volksgechichte differed fundamentally from Weimar Geschichts-Soziologie and the French formations examined below. If we are interested in the quality of research we have to consider scientific autonomy alongside the relative parity of the participants and the processual qualities of interdisciplinarity. And it is evident that scientific autonomy also has subjective sources rooted in the scientific habitus and ethics of the individual researcher (Steinmetz 2009).

To provide a sense of the distortions and limits introduced by selfheteronomization in historical research we can briefly examine the founder of Strukturgeschichte after 1945, Werner Conze. Alongside Theodor Schieder, the other key figure in postwar German social history, Conze began his career as a Nazi ethnic historian (Iggers 2005: xiv; Wehler 1977: 70-73). He studied with sociologists Hans Freyer and Gunter Ipsen, and Ipsen supervised Conze's doctoral and habilitation theses. Conze was widely seen as a sociologist before 1945, and was later described as a pioneer of "social history between sociology and history" (Schieder 1987).

Conze's work during the Nazi period combined historical and demographic methods with a comparative design and the sociology of Freyer and Ipsen. Conze compared family patterns among ethnic Germans and Poles in Northeastern Poland between the sixteenth and eighteenth centuries. He followed Ipsen in arguing that German landholding patterns, which had ended with the emancipation of the serfs in 1864, had been more successful in controlling population and preventing pauperization (Dunkhase 2010). In a paper written for the 1939 Bucharest meeting of the International Sociological Institute, Conze adopted the stance of a "policy sociologist," recommending German colonization of Poland and the reintroduction of the old German land ordinances, as well as the active "Entjudung" (dejudaization) of the 
cities and towns. ${ }^{17}$ These Nazified arguments were combined with information generated by Conze through ethnographic and archival research and presented as a mixture of sociological and historical genres.

The historians and sociologists concentrated at Königsberg and Leipzig during the Nazi period were able to reconstitute their networks in West Germany after 1945 and continue their collaboration. At the second postwar meeting of the German Historians Association in 1951 there was a long discussion of relations between history and sociology. Conze continued to insist on the "fluid" boundaries between the two disciplines and argued that that they should "influence one another" even "more intensively" (Conze 1952: 652, 656). A new opportunity for interdisciplinarity was provided by a governmentsponsored project on the expulsion of Germans from east-central Europe. This survey resembled Nazi-era Ostforschung in its combination of historical and sociological methods (Beer 1998). It was directed by Schieder and included Conze as well as younger social historians Martin Broszat and Hans-Ulrich Wehler. The expellees project also included Elisabeth Pfeil, a leading figure in Nazi-era "population science" (Schnitzler 2012) who became an expert on refugee questions and urban sociology after the war. Another participant was Eugen Lemberg, an expert in ethnic questions - the typical specialization for fascistic Central European sociologists in the mid-twentieth century.

Discussions among these networks of historians and sociologists continued in the Arbeitskreis für moderne Sozialgeschichte, a working group created in 1956 by Conze, with help from Carl Jantke, another sociologist-historian and former Königsberg professor. Jantke was professor of sociology at the Akademie für Gemeinwirtschaft in Hamburg (1953-1957) and professor of "Sociology and Economic/Social History" at Hamburg University starting in 1957. Jantke's professorship was the only one combining history and sociology in Germany at the time. The Arbeitskreis included two other sociologists: Conze's former advisor Ipsen, who was now in charge of the Dortmund Sozialforschungsstelle (Social Research Institute), and Georg Weippert, who taught at Königsberg between 1938 and 1945 and was a sociology professor at Erlangen after the war (Klingemann 2009: 103). At the early meetings of the Arbeitskreis, the sociologists were as critical of German sociology's "imperialism" and resurgent positivism as the historians were of traditional historiography. Jantke argued that sociology and history should be "interlocked to such an extent that in the end something new and instructive emerges" (Conze 1979: 27), and warned historians against accepting sociologists' "general concepts" or "fashionable formulas" (quoted in Klingemann 2009: 355).

The wartime interdisciplinary constellation was able to survive for several reasons. One set of reasons was material: the creation of employment for these

17 Conze (1940: 48); see also Conze (1938: 658). Although the Bucharest meetings were cancelled, the papers were published. 
researchers and the financial support that the Arbeitskreis received from the German Interior Ministry. These historians and sociologists were tied to one another through Nazi-era networks of friendship and collaboration. They continued to share intellectual interests. And both of the partners in this venturehistorical sociologists and social historians-were dominated within their respective disciplines at the time.

If we consider the two disciplinary fields historically, over time, however, into the 1960s and beyond, we can see why this interdisciplinary alliance was fated to disappear. The historicist sociologists were steadily losing power within their discipline, while the social historians were ascendant within their own discipline. The intersection of these two temporal sequences ended the interdisciplinary formation.

The growing lack of fit between historical sociologists and social historians is illustrated by the ways the new generations of social historians related to sociology - above all Hans-Ulrich Wehler, leader of the "Bielefeld school" of so-called historical social science. Wehler (born 1931) was closely tied to the leading figures of the Königsberg circle and the Arbeitskreis. He wrote his dissertation under Schieder and worked on the German expellee project in the 1950s (Beer 1998: 350). Conze wrote the lead chapter for Wehler's collection, Moderne Deutsche Sozialgeschichte (1968). Coming into his own, Wehler initially focused on recovering the work of previously marginalized social historians and historical sociologists (Wehler 1971-1982), and edited a collection on the history-sociology nexus (Wehler 1972). But Wehler increasingly distanced himself from the previous history-sociology constellation and from actual German sociologists, even while continuing to proclaim the virtues of interdisciplinarity.

There are several reasons for this divorce. Some now argued that German historicism was inherently conservative (Lukács 1981). Nazi-era scholars started losing legitimacy in West Germany, belatedly, in the late 1960s.

Second, Wehler's fading commitment to interaction with sociology corresponded to the widening gap between the status of social history and historical sociology within their respective disciplines. Social history moved to the top of its discipline. Conversely, the sociologists most attuned to history tended to be anti-positivist, to reject regularity determinism, and to work on the more distant past, positioning them ever further outside the sociological mainstream.

Third, sociology as a whole was becoming more of an irritant to history. History lost "much of its public relevance as a Leitwissenschaft or leading science" in Germany and elsewhere starting in the 1960s, with the "social sciences, above all sociology and political science, threaten[ing] to take over this role" (Stelzel 2010: 222). In the 1970s sociology seemed to be on the verge of overtaking history in terms of the number of university posts.

Wehler abandoned any pretense of open-ended and symmetrical interactions with sociology in the 1970 s. Sociological ideas were now processed on 
historians' terms with no input from living German sociologists. This strategy was combined with a spatial and temporal dislocation: sociological concepts were imported from abroad - specifically from the United States - and from the past (Max Weber), but not from contemporary German sociologists. Wehler endorsed American modernization theory (Wehler 1975) and an Americanized version of Max Weber, filtered through Talcott Parsons and stripped of Weber's historicism and interpretivism (Breuer 1988; Welskopp 2010: 13).

Wehler's increasingly aggressive and anxious responses to new intellectual trends and ideas also reflected the fact that his version of social history was coming under attack from several different directions just as it had reached the pinnacle of its power within the disciplinary field. It was challenged from within by the historians of everyday life (Alltagsgeschichte) and from abroad by critics of Wehler's "German exceptionalism" framework (Blackbourn and Eley 1984). Wehler conceded that his school might "risk an experiment with Bourdieu or Geertz" (Hardtwig and Wehler 1996: 10), while drawing a hard line against any serious engagement with Foucault.

Comparing the Bielefeld group's programmatic statements with its publications furnishes further evidence of the limited and dislocated character of its relations with sociology. The key journal, Geschichte und Gesellschaft (GuG), was founded in 1975 with the subtitle "Historical Social Science." In 1974 Wehler described this as an interdisciplinary journal and characterized his version of social history as "historical social science, in close cooperation with related social sciences, above all sociology, political science, and economics" (Stelzel 2010: 190). Yet $G u G$ published only a handful of articles by nonhistorians, in contrast with Annales, the journal to which it often compared itself. Annales had two prominent sociologists on its managing editorial board between 1929 and 1978: Maurice Halbwachs (until 1944) and Georges Friedmann (1946-1978), and both published frequently in the journal. By contrast, all of the managing editors of $G u G$ were historians. The journal's advisory committee included three non-historians, all based in the United States, and only one of them, Rueschemeyer, ever published in $G u G$. Between 1975 and 2000 there were fewer than ten contributions by sociologists. ${ }^{18}$ One political scientist called attention to the "estrangement of historical research from the social sciences" in the pages of $G u G$ (Ziebura 1990: 83).

A recent article by Bielefeld historian Thomas Welskopp suggests that there are new barriers to interdisciplinary interaction with sociologists. The only ongoing sociological work that could interest historians, Welskopp argues, is "mostly qualitative" and therefore represents "a minority in the [sociology] discipline" (2010: 36). A historical school that fears its own declining influence seems reluctant to align itself with scholars perceived as marginal

${ }^{18} G u G$ published a somewhat larger number of articles by political scientists during this period, but most were concentrated in the years after German unification and dealt with that question. 
within their disciplines. Ironically, it is only in Germany that qualitative and historical sociology represents "a minority" in its own discipline. In the American Sociological Association, the historical sociology section alone has over eight hundred members (as of September 2016) - the seventh largest section out of fifty-two; the overwhelmingly "qualitative" section on the sociology of culture has 1,078 members - more than any other section besides "Sex and Gender." 19 But this is the American Sociological Association, not the German one. Obviously, the reference groups for social science are still overwhelmingly national, and even local.

Welskopp's unease points to an important difference in the trajectories of the two putative interlocutors: social history is on a downward trajectory, while a historically oriented "qualitative" sociology has not been dominant in Germany since 1933. Structural homologies cannot be evaluated synchronically but have to be placed within their respective historical trajectories. The anxieties expressed in Welskopp's article make sense from the standpoint of a historicized field theory attentive to the non-synchronicity of disciplines' evolution.

To recapitulate: Most historians before 1933 were politically and methodologically conservative. Overtures to historians by historicist sociologists were generally rebuffed. After 1933, however, Nazi-oriented historians turned increasingly to "social" history, combining ethnographic and archival methods and shifting their attention to the previously disdained present. This entailed an opening to sociology. As a smaller and weaker discipline, sociology posed no institutional threat. But serious academic history, however politically conservative, was also under threat, like all scholarly work, due to the Nazi regime. The resulting interdisciplinary configuration survived the Nazi era and led to the establishment of social history after 1945 in West Germany. This relative structural parity between the two disciplines lasted until the $1960 \mathrm{~s}$, and then started to come out of joint. Social history is on a downward trajectory, while a historically oriented "qualitative" sociology has been marginal since the Nazi era. The two disciplines drifted apart and have never re-converged.

In sum, basic differences in the morphology, institutional power, and diachronic trajectories of the two disciplines shed light on their interrelations. Structural homologies cannot be evaluated synchronically but have to be placed within their respective historical trajectories.

IV.RELATIONS BETWEEN ACADEMIC SOCIOLOGY AND HISTORY IN TWENTIETH - CENTURY FRANCE

In light of the preceding discussion we might predict that intellectually fruitful interactions between historians and sociologists occur when the two disciplines

19 Data courtesy of the American Sociological Association. 
are relatively equal in power and where social science is more autonomous. These two conditions were met in France between the wars, around the journal Annales, and again after the mid-1980s, around Pierre Bourdieu. Both rapprochements occurred during crises of recruitment and succession in the two professions (Noiriel 1996). Both rapprochements took the form of a processual, dialectical interaction in which parts of the two disciplines interpenetrated, rather than a rigid division of disciplinary labor. In both periods the subgroups that approached one another were drawn from the autonomous, heterodox, research-oriented sectors of their respective disciplines.

\section{The Institutional Evolution of History and Sociology in France since 1900}

History was an ancient pursuit, but it was only able to establish itself as an independent academic discipline and divorce itself from the literary, philosophical, and political worlds during the 1880s (Noiriel 1990). Full-time historians possessing advanced degrees now began to displace amateur historians and local dignitaries (Dumoulin 1986: 53-54), defining a "distinct research tradition that [could] be passed from generation to generation" (Noiriel 1990: 77, 82). A key moment in history's disciplinary constitution was the creation in 1868 of the École Pratique des Hautes Etudes (EPHE) — an institution of higher education and research whose Fourth Section was dedicated to the historical and philological sciences. Teaching posts for historians increased after 1870, reaching thirty-two in 1898 and forty-one in 1914 (Rebérioux 1983: 221). That historians occupied important ministerial posts in the early Third Republic contributed to the discipline's success (Keylor 1975).

History's expansion slowed in the 1920s. There was an "overproduction of university degree-holders" and a "general stagnation in the number of teaching positions" throughout the human sciences (Heilbron 2015: 112). During the second half of the 1930s historians began to gain access to funding from the organization that became the CNRS (Dumoulin 1986: 55). History alone, of all of the human sciences, could now offer students some semblance of a stabilized career (Revel and Chartier 1979: 436).

The "trente glorieuses" - the thirty years of economic growth after 1945had dramatic effects on the human sciences. Between 1945 and 1968 "social science research in France grew from a minute, marginal intellectual activity, involving a mere handful of people, into a large-scale national service, spending millions of francs and employing thousands" (Machin 1984: 151). By the mid-1970s there were fifteen hundred historians in universities and research. At the beginning of the twenty-first century the CNRS section for Modern and Contemporary History had more than a thousand researchers (Martin 2005).

Sociology's evolution diverged sharply from this pattern. Durkheimian sociology emerged out of a rupture with the dominant school of French philosophy, Spiritualism (Fabiani 1988; Nicolas 2007). Spiritualism was "a conservative position" associated with "supporters of an elitist bourgeois politics and 
Catholic Christianity" that emphasized "the creative choices of individual minds as the driving force of reality" (Gutting 2001: 9, 12-13). Durkheim's doctrines, with their anti-individualism and anti-Spiritualism, and his followers' overwhelmingly liberal, Dreyfusard sensibilities, represented a heterodox position within French philosophy. This encouraged Durkheim to situate his program on the hitherto unoccupied terrain of sociology (Lukes 1985). French sociology did not disappear between the wars, despite the Durkheimians" "semi-failure" (Karady 1976) to establish themselves in the academy. Still, the discipline consisted almost entirely of a few journals, professional associations, and professorships, and its boundaries were loosely controlled (Heilbron 2015: 96).

Sociology grew much more rapidly and consolidated itself as a more bounded field after 1945. Starting in 1958, students could earn a licence in sociology. In 1966 economics and sociology were introduced into French secondary education (Heilbron 2015: 166). Sociological research after 1945 consisted mainly of research carried out by CNRS researchers, "who outnumbered university sociologists until well into the 1970s" (ibid.: 135). By the mid-1960s the CNRS had around 130 sociology researchers; their numbers rose to 340 in 1983. This remained stable until 1990 and then declined to around two hundred by 2013 (Lautman 2012: 183; Heilbron 2015: 163-64).

In sum, sociology congealed as an academic field somewhat later than history, and historians outnumbered sociologists in higher education and research even after the expansion of sociology in the 1960s and 1970s. At the beginning of the twenty-first century, history was delivering twice as many doctoral degrees as sociology (Piriou 2008, table 3) and had four times as many CNRS positions. Yet these numbers cannot fully explain patterns of interdisciplinary attraction, which are underwritten by structural homologies and resonances between subdisciplines and specific positions, disciplinary and subdisciplinary trajectories, and convergent intellectual questions.

\section{French Sociology and History before 1914: The Durkheimian Challenge}

History, not philosophy, was the discipline with which the Durkheimians had the most ferocious controversies (Besnard 1983: 248). Before World War I most French historians looked at sociology with an attitude of "smiling condescension and slight disdain" (Rebérioux 1983: 223). Durkheim defined social science in terms of causal regularities (Durkheim 1982: 232-33), arguing in the first issue of Année sociologique that "history cannot be a science except if it is explanatory, and it cannot explain other than through comparison," and concluding that "as soon as it compares, history becomes indistinguishable from sociology" (Durkheim 1898: ii-iii). Individuals and contingent events were an irrational residue best left to the historicizing historians. As Durkheim said, "I admire the historians who can live comfortably amid this pile of disordered events," this "indefinite mountain of facts" (1982: 224). 
A few younger historians were attracted to Durkheim's views and twoHenri Hubert and Georges Bourgin - became regular contributors to L'Année sociologique. Marc Bloch and Lucien Febvre, future founders of Annales, were already inspired by Durkheim to raise "questions about certain of [their] discipline's methodological premises” (Besnard 1983: 250). Philosopher François Simiand (1903) agreed with Durkheim that history could only become scientific by establishing invariant causal sequences and ignoring unique individuals and accidental contingencies (Leroux 1998: 191-229). The counterattack by historians Langlois and Seignobos defended disciplinary boundaries and staked out a claim to "a position of hegemony in the field of the social sciences" (Besnard 1983: 250; Leroux 1998: 84-88).

Historians closer to Durkheim tended to be younger (like Bloch and Febvre) and poorly integrated into the university (e.g., Lacombe, who was general inspector of libraries and archives but not a history professor). They were not part of the "history establishment" (Revel and Chartier 1979: 431). Hence there was little common ground between sociologists and historians before 1914 .

\section{The Annales School and the Emergence of Sociological Neo-Historicism: Relative Parity and the Fusion of Perspectives}

Conditions for sustained interaction between historians and sociologists became more propitious after 1918. First, sociologists now articulated a more tolerant stance toward historians. Marcel Mauss, who assumed leadership over the postwar Durkheimians, assured historians that sociologists had no intention of trying to annex them (1925: 246; also Bouglé 1934: 177). Sociologists stopped insisting on regularity determinism. And sociology had also become much less threatening institutionally with the devastation of the Durkheimian team through deaths in World War I.

A key development on the other side was the entry of a new generation of historians into the discipline. The leaders of the movement against empiricist, atheoretical history, Bloch and Febvre, both secured chairs at the University of Strasbourg and created the journal Annales in 1929. Both historians moved to the center of the academic world in the mid-1930s, Febvre by joining the Collège de France in 1933, Bloch by moving to the Sorbonne in 1935. Their younger collaborators, however, were entering the history profession at a moment of severe crisis (Dumoulin 1986). This solidified the structural affinity between the new historians and sociologists, most of whom were also located in tenuous institutional conditions.

Strong connections between Durkheimian sociology and Annales historiography were also underwritten by a series of intellectual complementarities. The Annales program was defined "at its core" by the idea of "history and social sciences," or history as social science (Revel 1979: 1362). This entailed shifting historians' focus away from individuals, singular events, and great politics and toward social, cultural, and economic structures, along with an 
embrace of comparison (Berr and Febvre 1935). This also involved an opening to other disciplines: 18 percent of the articles in Annales between 1929 and 1938 were written by non-historians, and this proportion kept rising after 1945 (Raphael 1994: 216, 455). By the same token, Annales historians contributed to the revived second series of the Année sociologique and its successor, Annales sociologiques. Annales adopted from Durkheim's Année sociologique the model of a "scientific community defining itself as bearing a new and critical project" and claiming the right to review and criticize work from a variety of disciplines and to organize this work around its own unified framework (Revel and Chartier 1979: 431). In 1935, Febvre organized his project for the state-sponsored Encyclopédie Français around the "basic problems posed by Durkheimian sociology" (ibid.: 436). Bloch and Febvre were associated with the Revue de synthèse historique, a journal founded by Henri Berr in 1900 , from which they adopted the model of a collective project with different disciplines being brought to bear on a common object (Revel 1979: 1364). Sociology helped Annales historians wrestle with problems of generalization, comparison, collective consciousness, and causality.

Three leading French sociologists of the interwar period developed more nuanced, historicist views through their interactions with historians: Halbwachs, Célestin Bouglé, and Raymond Aron. The evolution from Halbwachs to Aron represents an increasing openness to historicist epistemologies.

Halbwachs held the first French university chair dedicated exclusively to sociology, at Strasbourg, and was the "most Durkheimian of the interwar Durkheimians" (Craig 1983: 263). He studied philosophy in Germany and France and became an acolyte of Bergson. After consulting with Durkheim and Mauss, Halbwachs retained his "Bergsonian preoccupation" with temporality, but concluded that it "was not inner time or duration that was of the essence but rather time as a social construction" (Coser 1992: 8). Even though much of Halbwachs' work between the wars was ahistorical and statistical, he became "a loyal and devoted member" of Annales (ibid.: 116), contributing ninety articles and reviews between 1929 and $1941 .^{20}$ The project for an Institute for Economic and Social History at the University of Paris in 1936 was written jointly by Bloch and Halbwachs (Dumoulin 1990: 99 n47). Halbwachs argued in the pages of Annales that French sociologists did not believe that sociology and history had distinct domains (Halbwachs 1932: 81).

The most productive exchange between Halbwachs and the Annales historians, one that took a dialectical, processual form, revolved around the topic of collective memory. Bloch reviewed Halbwachs' first book on the topic (Halbwachs 1925; Bloch 1925); Halbwachs referred to this review in

${ }^{20}$ These are my calculations. 
his second, posthumously published book on collective memory (1950: 50); Bloch included a chapter in Feudal Society (1939-1940) on collective memory, which he analyzed as something that was both "deliberately contrived" and unconscious - a Durkheimian rather than a Freudian formulation in this context. ${ }^{21}$

Célestin Bouglé was a member of the original Durkheimian circle who became a "patron" of French sociologists between the wars (Marcel 2001: 288). Although Bouglé initially articulated a classic Durkheimian position on history, he became more tolerant of historicism over time. His first book on German social science (Bouglé 1896) was written too early to take into account Rickert's neo-historicist solution to the putative division between "ideographic" and "nomothetic" approaches. By 1901, however, Bouglé worked through Rickert's arguments about explaining "unique events" with "the use of general concepts" (Bouglé 1901-1902: 140). Between 1934 and 1941 Bouglé contributed a series of articles entitled "History and Sociology" to Annales sociologiques. Here he argued that sociologists could study individuals who were "historical personalities" and that unique events were of sociological interest if they involved the "exercise of force- a conquest, for example," or if they took "the character of a transfer, an extension, or a deepening of civilization" (1934: 180). The fact that Bouglé made these arguments in a discussion of a paper by Febvre on "historical personalities" underscores the existence of an ongoing dialogue with Annales historians. In a subsequent publication Bouglé suggested that sociologists could explain unique events by seeking their "general conditions" or the causally relevant "institutional facts" (1935: 91).

The most explicit sociological opening to neo-historicism came from Raymond Aron, who studied in Germany between 1930 and 1933, when sociological neo-historicism was at its height. Aron met Mannheim and Norbert Elias and immersed himself in the work of Simmel, Dilthey, Rickert, Freyer, Schutz, Lukács, and "above all Weber" (Baverez 1993: 76, 80). Aron's La Sociologie allemande contemporaine (1935) contrasted German historical sociology with Durkheimianism and with German formal sociology. He clearly favored the historicist tendency, which he argued "tries to distinguish itself from history without excluding the uniqueness of development, the reality of accidents, or the specific character of different ages," and which "does not claim to establish laws, or a system, or a unilinear development of mankind" (1964 [1935]: 111). Bouglé and Aron had reached a position similar to that of Bloch (1953), who in his posthumously published book The Historian's Craft rejected the idea of causal regularities but favored historical comparison.

${ }^{21}$ Bloch 1939-1940, book I, ch. 3. 


\section{Braudel and the Disjuncture between Interdisciplinarity in Theory and in Practice}

After 1945 Febvre and Fernand Braudel solidified their relationship to the social sciences by associating Annales with the newly founded Sixth Section of the EPHE, and in 1956 Braudel became the school's director. In the tradition of the interwar Annales, Braudel called for interdisciplinary dialogue with the social sciences, especially sociology (Braudel 1980 [1958]). Numerous seminars were called "'Histoire et sociologie' of this or that area" (Hexter 1972: 491).

Nonetheless, Braudel's programmatic statements in the 1950s and 1960s clashed with the reality of interdisciplinary practice in ways that are reminiscent of the Bielefeld school in the 1970s and 1980s. Operating from a position of institutional strength, Annales interdisciplinarity at the time involved mainly one-sided appropriations of techniques and ideas associated with science or social science in general rather than current French sociology. Sociologist Georges Friedmann continued to publish in the Annales, but his industrial research had little to offer a history profession that was still focused on the mediaeval and early modern periods. Braudel's debate with sociologist Georges Gurvitch on questions of time and duration reveals the breakdown in interdisciplinary dialogue and a peculiar reversal of the epistemologies conventionally associated with the two disciplines. Braudel rejected Gurvitch's emphasis on the "discontinuous, contingent, and qualitative" and resistance to operationalization and measurement (Maillard 2005). The disciplines with the greatest impact on Braudel and Ernst Labrousse, another central figure in the postwar Annales School, were geography, economics, demography, and an economistic Marxism (Burke 2015: 61-64). Braudel's most sustained engagement with sociology occurred after his retirement in 1972, when his work began to be shaped by American sociologist Immanuel Wallerstein (ibid.: 57-58). By this time, however, the third generation of the Annales School had come to the fore, shifting its emphasis from the "cellar to the attic"- that is, to cultural or intellectual history (ibid.: 76).

How can we explain the disappearance of the sociology-history axis in the 1950 s and 1960s, when interdisciplinarity was being proclaimed as a universal good in the Sixth Section and French society more generally (Burguière 2005)? One reason is the intellectual gap between Braudel and postwar sociology's "intellectual pole," the most direct descendant of the interwar Durkheimians. At the center of French sociology's intellectual pole were two historicists, Aron and Gurvitch. History and sociology also related differently to existentialism. As Noiriel (1996: 98 n13) notes, a "common characteristic of all Annales historians during this period is the rejection of any and all explicit reliance on philosophy." A further wedge was driven between history and sociology by French structuralism, which reinvigorated theory in the social sciences but 
was resolutely synchronic and partly a social science riposte to the hegemonic ambitions of Annales-style social history (ibid.: 97). Contacts between historians and sociologists remained superficial throughout the postwar period (Raphael 1994: 263, 457).

French historians began to look to other disciplines beginning in the $1980 \mathrm{~s}$ in a "crisis of orientation" after rejecting Braudel (ibid.: 199). The shifts in this third generation set the stage for historians' encounter with Bourdieu. Many historians turned initially to literary theory, linguistics, and ethnology, but there was also renewed interest in Durkheimian and neo-Marxist ideas about collective conscience, mentalities, and ideology. An editorial in Annales in 1988 deplored the weakening of interdisciplinary alliances. The journal's subtitle was changed from the Braudelian "economies, societies, civilizations" to "History-Social Sciences" (Noiriel 1996: 22, 34).

\section{Bourdieu and the Historians since the 1980s: A Dialectical Fusion of Disciplines}

The realignment of the relationship between the disciplines that began in the 1980s was also prepared by developments in sociology. A new sociology of the social and human sciences began to appear in the 1970s, pioneered by Bourdieu and his collaborators (Victor Karady, Michel Pollak, Jean-Louis Fabiani, Johan Heilbron, etc.). Historian Jacques Revel (1979) already called attention to the importance of this work. Many of Bourdieu's students and colleagues engaged in projects that could be qualified as historical sociology, published in history journals, ${ }^{22}$ and eventually began to describe their own work as sociologie historique. ${ }^{23}$ The hallmarks of this work include the use of primary and archival sources, explicit conceptualization based at least partly on Bourdieu's theoretical armature, and an analytic strategy combining interpretation with explanation and embracing contingent, overdetermined, conjunctural analysis. Bourdieu's own work in the 1980s and 1990s became increasingly historicist in this sense. His accounts of changes in the fields of literature, painting, science, and the university during the nineteenth century and the events of May 1968 (Bourdieu 1988, ch. 5) are premised on a neo-historicist epistemology and an ontology of the social as a heterogeneous, open system and major events as unpredictable but post facto explicable. ${ }^{24}$

\footnotetext{
22 See Steinmetz (2011); and the list of theses written under the direction of Pierre Bourdieu at: http://pierrebourdieuunhommage.blogspot.fr/2012/11/theses-inscrites-sous-la-direction-de.html (accessed 31 Dec. 2016).

23 E.g., Fabiani (2015). One barrier to earlier adoption of the "sociologie historique" label by Bourdieusians was its association with Aron, from whom Bourdieu had become alienated in 1968 (Robbins 2011).

24 On the social as an open system, see Bhaskar 1986; and Steinmetz 1998. For the parallel notion of the heterogeneity of the social, see Little 2016.
} 
It is also noteworthy that Bourdieu invited "certain young historians to join the editorial committee" of his journal, Actes de la recherche (Chartier 2002: 85), and that Actes became "a venue for historiographic debate," publishing "at least seventy articles between 1975 and 1993 by historians who were often well-known and for whom the journal was thus neither a scientific exile nor a last resort" (Christin 2006: 148). The discussion between Bourdieu and a group of historians at a 1985 conference on French higher education in the nineteenth and twentieth centuries demonstrates that this was a symmetrical conversation spurred by convergent interests in the two disciplines (Charle and Ferré 1985; see also Charle 2013). Interviews with Bourdieu by German and French historians (Bourdieu and Raphael 1995; Bourdieu et al. 1995; Bourdieu and Chartier 2015) track the increasing interest among historians in Bourdieu's work during the 1990s. ${ }^{25}$ Burke (2015: 94) concludes that the work of the "fourth generation" of the Annales School was "affected ... pervasively" by Bourdieu.

\section{CONCLUSION: IN DEFENSE OF INTERDISCIPLINARITY-AND DIS CIPLINES}

This article has proposed a revisionist narrative of the relations between history and sociology. I have sought to discern the determinants of more fruitful forms of interdisciplinarity and tendencies to disciplinary closure and avoidance. In line with the neo-historicist epistemologies I have discussed here, I have not attempted to provide a general model but instead to single out several of the key determinants of intellectual practices rooted in institutions and the internal relational dynamics of disciplinary fields. Productive interdisciplinarity is driven by structural and intellectual affinities between members or sectors of different disciplines, intellectual interests that cannot be satisfied within the home discipline, and strategic interests pushing actors toward external allies. In the most generative situations, drawn-out dialogic processes led to the fusion of disciplinary perspectives and the production of new knowledge. These interdisciplinary practices were generated autonomously within disciplines, subdisciplines, and the spaces in between, and were not induced by external agents.

I located the first powerful formations of history-sociology syncretism in Weimar Germany and interwar France, between Annales historiography and post-Durkheimian sociology. I discussed an unfamiliar interdisciplinary formation in Nazi Germany and postwar West Germany. The most persuasive merging of the two disciplines, I argued, had emerged in France since the 1980s around the work of Pierre Bourdieu.

\footnotetext{
25 Elsewhere I argue that Bourdieu's key concepts, habitus, symbolic capital, and field, are inherently historical (2011).
} 
These intellectual-scientific configurations resulted from unique historical sequences and conjunctures. Social science is incapable of predicting novel or transformative events but can only explain them retroactively and retroductively. ${ }^{26}$ The successful cases of interdisciplinarity discussed here resulted from overdetermined and utterly serendipitous resonances and synchronicities. It is extremely unlikely that such conditions could be deliberately induced. The kinds of "top-down" interdisciplinarity preferred by administrators, research funders, and corporations are typically associated with shallower forms of interdisciplinarity. What a historical field analysis like this one can accomplish is to point to the necessary if not sufficient conditions for generative interdisciplinarity, and to identify likely nodes of resistance and receptiveness to such exchanges.

This paper has shown that the most productive forms of interdisciplinarity involved forays into adjacent disciplines motivated by intellectual, scientific, and strategic interests that were generated within existing disciplines. This leads me to a muted defense of disciplines, in the interest of interdisciplinarity. Disciplinary boundaries can shield science against outside pressures, help scientists exercise quality control, and generate new problems in an organic way. Although I have focused on threats to scientific autonomy from states and other institutions, such pressures also stem from other disciplines, as programs of "consilience" have shown (Wilson 1998; Jay 2011). Disciplinary fields and subfields allow interdisciplinary work itself to be subjected to evaluative assessments grounded in semi-autonomous procedures that have been elaborated over time and shown to protect science from external forces and to do more good than bad (Barrow 1990; Cole 2015). The fieldness of disciplines protects interdisciplinary moves from being coopted by bureaucratic and corporate logics. Disciplinarity is a precondition for scientific autonomy, and autonomy is a precondition not just for science but for the most fruitful forms of interdisciplinarity. ${ }^{27}$

This partial defense of disciplines goes hand in hand with full recognition of the arbitrariness and artificiality of existing divisions among social science disciplines. We may have to accept this arbitrariness in order to defend procedures of judgmental rationality and ward off scientific heteronomization. Whether these bounded fields should be called disciplines is a different matter. The connotations of the word discipline, since Foucault, include the idea of external control, which is what we are trying to avoid. The phase "semiautonomous scientific fields" would be preferable.

26 Steinmetz 1998. On scientific retroduction (also labeled abduction), see Peirce 1931: 29 [1.68]; and Bhaskar 1997 [1975]; 1986.

27 Although this argument for the need to combine disciplines with interdisciplinarity is similar to Jacobs (2013) and Graff (2015), I want to emphasize that I have arrived at this argument through an entirely different theoretical perspective and that this is not the only argument in the present article. 
REFERENCES

Abbott, Andrew. 1999. Department \& Discipline: Chicago Sociology at One Hundred. Chicago: University of Chicago Press.

Adams, Julia, Elisabeth S. Clemens, and Ann Shola Orloff, eds. 2005. Remaking Modernity: Politics, History, and Sociology. Durham: Duke University Press.

Aron, Raymond. 1964 [1935]. German Sociology. Glencoe: Free Press.

Barrow, Clyde W. 1990. Universities and the Capitalist State: Corporate Liberalism and the Reconstruction of American Higher Education, 1894-1928. Madison: University of Wisconsin Press.

Baverez, Nicolas. 1993. Raymond Aron: un moraliste au temps des ideologies. Paris: Flammarion.

Beer, Mathias. 1998. Im Spannungsfeld von Politik und Zeitgeschichte. Vierteljahrshefte für Zeitgeschichte 46, 3: 345-89.

Beiser, Frederick C. 2011. The German Historicist Tradition. Oxford: Oxford University Press.

Below, Georg von. 1919. Soziologie als Lehrfach. Schmollers Jahrbuch 43, 4: 59-110.

Berr, Henri and Lucien Febvre. 1935. History. In Edwin Seligman and Alvin Johnson, eds., Encyclopedia of the Social Sciences, vol. 7. New York: Macmillan, 357-68.

Besnard, Philippe. 1983. The Epistemological Polemic: François Simiand. In Philippe Besnard, ed., The Sociological Domain: The Durkheimians and the Founding of French Sociology. Cambridge: Cambridge University Press, 248-62.

Bhaskar, Roy. 1979. The Possibility of Naturalism: A Philosophical Critique of the Contemporary Human Sciences. Atlantic Highlands: Humanities Press.

Bhaskar, Roy. 1986. Scientific Realism and Human Emancipation. London: Verso.

Bhaskar, Roy. 1997 [1975]. A Realist Theory of Science. London: Verso.

Blackbourn, David and Geoff Eley. 1984. The Peculiarities of German History. New York: Oxford University Press.

Bloch, Marc. 1925. Memoire collective, tradition et coutume. Revue de synthese historique 40: 73-83.

Bloch, Marc. 1939-1940. La société féodale, vol. 1. Paris: A. Michel.

Bloch, Marc. 1953. The Historian's Craft. New York: Knopf.

Bouglé, Célestin. 1896. Les sciences sociales en Allemagne: Les methodes actuelles. Paris: F. Alcan.

Bouglé, Célestin. 1901-1902. Review of Revue de synthèse. Année sociologique, series 1, 5: $138-40$.

Bouglé, Célestin. 1934. Histoire et sociologie: remarques générales. Annales sociologiques, series A, 1: 172-82.

Bouglé, Célestin. 1935. Bilan de la sociologie française contemporaine. Paris: Alcan.

Bourdieu, Pierre. 1988. Homo Academicus. Cambridge: Polity Press.

Bourdieu, Pierre. 1991. On the Possibility of a Field of World Sociology. In Pierre Bourdieu and James S. Coleman, eds., Social Theory for a Changing Society. Boulder: Westview Press, 373-87.

Bourdieu, Pierre. 1993. Some Properties of Fields. In Sociology in Question. London: Sage, 72-77.

Bourdieu, Pierre. 1996. The Rules of Art. Cambridge: Polity Press.

Bourdieu, Pierre. 1998. On Television. New York: The New Press.

Bourdieu, Pierre. 2013. Manet: une révolution symbolique. Paris: Seuil.

Bourdieu, Pierre and Roger Chartier. 2015. The Sociologist and the Historian. Cambridge: Polity Press.

Bourdieu, Pierre and Lutz Raphael. 1995. Sur les rapports entre la sociologie et l'histoire en Allemagne et en France. Actes de la recherche en sciences sociales 106-7: 108-22. 
Bourdieu, Pierre, et al. 1995. Deux séminaires (Paris-Gôttingen). Actes de la recherche en sciences sociales 106-7: 102-4.

Braudel, Fernand. 1980 [1958]. History and Sociology. In On History. Chicago: University of Chicago Press, 64-82.

Breuer, Stefan. 1988. Max Weber als Historiker. Rechtshistorisches Journal 7: 80-83.

Bühl, Walter Ludwig. 2003. Historische Soziologie: Theoreme und Methoden. Münster: Lit.

Burguière, André. 2005. Plozévet, une mystique de l'interdisciplinarité? Cahiers $d u$ Centre de recherches historiques 36: 231-63.

Burke, Peter. 2015. The French Historical Revolution: The Annales School, 1929-2014. 2d ed. Stanford: Stanford University Press.

Burleigh, Michael. 1988. Germany Turns Eastwards: A Study of Ostforschung in the Third Reich. Cambridge: Cambridge University Press.

Calhoun, Craig. 1996. The Rise and Domestication of Historical Sociology. In Terrence J. McDonald, ed., The Historic Turn in the Human Sciences. Ann Arbor: University of Michigan Press, 305-38.

Charle, Christophe. 2013. Homo historicus: réflexions sur l'histoire, les historiens et les sciences sociales. Paris: Armand Colin.

Charle, Christophe and Régine Ferré, eds. 1985. Le Personnel de l'enseignement supérieur en France aux XIXe et XXe siécles. Paris: Éditions du Centre national de la recherche scientifique.

Chartier, Roger. 2002. Le sociologue et l'historien. Entretien. Sciences humaines, special issue: $80-85$.

Christin, Olivier. 2006. La discipline historique et Bourdieu. In Hans-Peter Müller and Yves Sintomer, eds., Pierre Bourdieu, théorie et pratique. Paris: Découverte, 146-54.

Cole, Jonathan R. 2015. Academic Freedom under Fire. In Akeel Bilgrami and Jonathan R. Cole, eds., Who's Afraid of Academic Freedom? New York: Columbia University Press, 40-56.

Collini, Stefan. 1985. What Is Intellectual History? History Today 35, 10: 46-48.

Conze, Werner. 1938. Wilna und der Nordosten Polens. Osteuropa: Zeitschrift für die gesamten Fragen des europischen Ostens 13: 657-64.

Conze, Werner. 1940. Die ländliche Überbevölkerung in Polen. In Travaux du XIVe congrès international de sociologie Bucuresti (1939), Communications, Série $\mathrm{B}$, Le village, vol. 1, 40-48.

Conze, Werner. 1952. Die Stellung der Sozialgeschichte in Forschung und Unterricht. Geschichte in Wissenschaft und Unterricht 3: 648-57.

Conze, Werner. 1977. Die deutsche Geschichtswissenschaft seit 1945: Bedingungen und Ergebnisse. Historische Zeitschrift 225, 1: 1-28.

Conze, Werner. 1979. Die Gründung des Arbeitskreises für moderne Sozialgeschichte. Hamburger Jahrbuch für Wirtschafts- und Gesellschaftspolitik 24: 23-32.

Coser, Lewis A. 1992. Introduction. In Maurice Halbwachs, ed., On Collective Memory. Chicago: University of Chicago Press, 1-34.

Craig, John E. 1983. Sociology and the Related Disciplines between the Wars: Maurice Halbwachs and the Imperialism of the Durkheimians. In Philippe Besnard, ed., The Sociological Domain: The Durkheimians and the Founding of French Sociology. Cambridge: Cambridge University Press, 263-89.

Dörk, Uwe and Henning Borggräfe. 2015. Wissen und Organisation. Die Deutsche Gesellschaft für Soziologie und der Historikerverband. Comparativ: Leipziger Beiträge zur Universalgeschichte und vergleichenden Gesellschaftsforschung 25, 1-2: 19-35. 
Dumoulin, Olivier. 1986. Le professionalization de l'histoire en France (1919-1939). In Société française de sociologie, ed., Historiens et sociologues aujourd'hui. Paris: CNRS, 49-60.

Dumoulin, Olivier. 1990. Changer l'histoire. Marché universitaire et innovation intellectuelle à l'époque de Marc Bloch. In Hartmut Atsma and André Burguière, eds., Marc Bloch aujourd'hui. Paris: Éditions de l'EHESS, 87-104.

Dunkhase, Jan Eike. 2010. Werner Conze: ein deutscher Historiker im 20. Jahrhundert. Göttingen: Vandenhoeck \& Ruprecht.

Durkheim, Émile. 1898. Préface. L'Année sociologique 1: i-vii.

Durkheim, Émile. 1982. Debate on Explanation in History and Sociology. In Steven Lukes, ed., The Rules of Sociological Method. London: Macmillan, 211-28.

Fabiani, Jean-Louis. 1988. Les Philosophes de la République. Paris: Les Éditions De Minuit.

Fabiani, Jean-Louis. 2015. La sociologie par les textes. Sciences humaines 273 (Aug.Sept.): $28-31$.

Fischer, Peter. 2008. Historische Soziologie als Kultursoziologie? Hamburg Review of Social Sciences 3: 172-92.

Fligstein, Neil and Doug McAdam. 2012. A Theory of Fields. New York: Oxford University Press.

Francis, Emerich. 1951. History and the Social Sciences: Some Reflections on the Re-Integration of Social Science. Review of Politics 13: 354-74.

Freyer, Hans. 1948. Weltgeschichte Europas. 2 vols. Wiesbaden: Dieterich.

Frickel, Scott and Ali O. Ilhan. 2016. Disciplinary and Interdisciplinary Change in Six Social Sciences: A Longitudinal Comparison. In Scott Frickel, Mathieu Albert, and Barbara Prainsack, eds., Investigating Interdisciplinary Collaboration: Theory and Practice across Disciplines. New Brunswick: Rutgers University Press, 148-72.

Georgakakis, Didier and Antoine Vauchez. 2015. Le concept de champ à l'épreuve de l'Europe. In Johanna Siméant, ed., Guide de l'enquête globale en sciences sociales. Paris: CNRS, 197-217.

Gingras, Yves. 2014. L'historien dans la Cité: l'objectivation contre l'instrumentalisation. Bulletin d'histoire politique 22, 3: 265-86.

Gorski, Phil. 2013. Bourdieusian Theory and Historical Analysis. In Phil Gorski, ed., Bourdieusian Theory and Historical Analysis. Durham: Duke University Press, 327-66.

Graff, Harvey J. 2015. Undisciplining Knowledge: Interdisciplinarity in the Twentieth Century. Baltimore: Johns Hopkins University Press.

Gulbenkian Commission. 1997. Open the Social Sciences. Stanford: Stanford University Press.

Gutberger, Jörg. 1996. Volk, Raum, und Sozialstruktur: Sozialstruktur- und Sozialraumforschung im "Dritten Reich.” Munster: LIT Verlag.

Gutting, Gary. 2001. French Philosophy in the Twentieth Century. Cambridge: Cambridge University Press.

Haar, Ingo and Michael Fahlbusch, eds. 2005. German Scholars and Ethnic Cleansing (1920-1945). New York: Berghahn Books.

Halbwachs, Maurice. 1925. Les cadres sociaux de la mémoire. Paris: Alcan.

Halbwachs, Maurice. 1932. La sociologie en Allemagne et aux Etats-Unis. Annales d'histoire économique et sociale 4, 13: 80-81.

Halbwachs, Maurice 1950. La mémoire collective. Paris: Presses universitaires de France.

Hall, John A. 1989. They Do Things Differently There, or, the Contribution of British Historical Sociology. British Journal of Sociology 40: 544-64. 
Hardtwig, Wolfgang and Hans-Ulrich Wehler. 1996. Einleitung. In Kulturgeschichte heute. Göttingen: Vandenhoeck \& Ruprecht, 7-13.

Hasberg, Wolfgang and Manfred Seidenfuss, eds. 2005. Geschichtsdidaktik(er) im Griff des Nationalsozialismus? Münster: Lit.

Heilbron, Johan. 2008. Qu'est-ce qu'une tradition nationale en sciences sociales? Revue d'histoire des sciences humaines 18: 3-16.

Heilbron, Johan. 2015. French Sociology. Ithaca: Cornell University Press.

Hesketh, Ian. 2011. The Science of History in Victorian Britain. London: Pickering \& Chatto.

Hexter, J. H. 1972. Fernand Braudel and the Monde Braudellien.... Journal of Modern History 44, 4: 480-539.

Iggers, Georg G. 1997. Historiography in the Twentieth Century. Hanover: Wesleyan University Press.

Iggers, George G. 2005. Foreword. In Ingo Haar and Michael Fahlbusch, eds., German Scholars and Ethnic Cleansing (1920-1945). New York: Berghahn Books, vii-xviii.

Jacobs, Jerry A. 2013. In Defense of Disciplines: Interdisciplinarity and Specialization in the Research University. Chicago: University of Chicago Press.

Jacobs, Jerry A. and Scott Frickel. 2009. Interdisciplinarity: A Critical Assessment. Annual Review of Sociology 35, 43-65.

Jay, Martin. 2011. The Menace of Consilience. In Raphael Foshay, ed., Valences of Interdisciplinarity: Theory, Practice, Pedagogy. Edmonton, AB: Athabasca University Press, 31-46.

Kaesler, Dirk. 1984. Die frühe deutsche Soziologie 1900 bis 1934 und ihre EntstehungsMilieus. Opladen: Westdeutscher Verlag.

Karady, Victor. 1976. Emile Durkheim, les sciences sociales et l'Université: bilan d'un semi-échec. Revue française de sociologie 17, 2: 267-311.

Kater, Michael H. 1991. Refugee Historians in America: Preemigration Germany to 1939. In Hartmut Lehmann and James J. Sheehan, eds., An Interrupted Past: German-Speaking Refugee Historians in the United States after 1933. New York: Cambridge University Press, 73-93.

Kershaw, Ian. 1993. Working Towards the Führer: Reflections on the Nature of the Hitler Dictatorship. Contemporary European History 2, 2: 103-18.

Keylor, William R. 1975. Academy and Community: The Foundation of the French Historical Profession. Cambridge: Harvard University Press.

Klingemann, Carsten. 1996. Soziologie im Dritten Reich. Sinzheim: Nomos-Verlag, Baden-Baden.

Klingemann, Carsten. 2009. Soziologie und Politik: Sozialwissenschaftliches Expertenwissen im Dritten Reich und in der frühen westdeutschen Nachkriegszeit. Wiesbaden: VS Verlag für Sozialwissenschaften.

Kuklick, Henrika. 1983. The Sociology of Knowledge: Retrospect and Prospect. Annual Review of Sociology 9: 287-310.

Lacombe, Paul. 1894. De l'histoire considérée comme science. Paris: Hachette.

Langewiesche, Dieter. 1997. Die Universität Tübingen in der Zeit des Nationalsozialismus: Formen der Selbstgleichstaltung und Selbstbehauptung. Geschichte und Gesellschaft 23: 618-46.

Lautman, Jacques. 2012. Le CNRS et la sociologie. Histoire de la recherche contemporaine 2, 2: $182-88$.

Lenoir, Timothy. 1997. Instituting Science: The Cultural Production of Scientific Disciplines. Stanford: Stanford University Press.

Leroux, Robert. 1998. Histoire et sociologie en France: de l'histoire-science à la sociologie durkheimienne. Paris: Presses Universitaires de France. 
Lindenfeld, David F. 1997. The Practical Imagination: The German Sciences of State in the Nineteenth Century. Chicago: University of Chicago Press.

Little, Daniel. 2016. New Directions in the Philosophy of Social Science. London: Rowman \& Littlefield.

Lukács, György. 1981. The Destruction of Reason. Atlantic Highlands: Humanities Press.

Lukes, S. 1985. Emile Durkheim. Stanford: Stanford University Press.

Machin, Howard. 1984. The CNRS and Social Science Research in France. In Edmond Lisle, Howard Machin, and Sy Yasin, eds., Traversing the Crisis: The Social Sciences in Britain and France. London: Economic and Social Research Council, 145-239.

Maillard, Alain. 2005. Les temps de l'historien et du sociologue. Retour sur la dispute Braudel-Gurvitch. Cahiers internationaux de sociologie 119: 197-222.

Mannheim, Karl. 1932. Die Gegenwartsaufgaben der Soziologie: ihre Lehrgestalt. Tübingen: Mohr.

Mannheim, Karl. 1934. German Sociology (1918-1933). Politica (Feb.): 12-33.

Mannheim, Karl. 1952 [1924]. Historicism. In Essays on the Sociology of Knowledge. Paul Kecskemeti, ed. London: Routlege and Kegan Paul, 84-133.

Marcel, Jean-Christophe. 2001. Le Durkheimisme dans l'entre-deux guerres. Paris: PUF.

Martin, Olivier. 2005. Une étude des institutions de la recherche en histoire, philosophie et sociologie des sciences. La revue pour l'histoire du CNRS 13 (Nov.). At: http:// histoire-cnrs.revues.org/1614 (consulted 16 May 2016).

Marx, Karl. 1970. The German Ideology, Chapter 1. In Karl Marx and Friedrich Engels, Selected Works, vol. 1. Moscow: Progress, 16-80.

Mau, Steffen and Denis Huschka. 2010. Who Is Who? Die Sozialstruktur der Soziologie-Professorenschaft in Deutschland. Kölner Zeitschrift für Soziologie und Sozialpsychologie 62: 751-66.

Mauss, Marcel. 1925. Review of Henri Berr. L'évolution de l'humanité. Année sociologique ser. 2, vol. 1: 289-90.

Mihic, S., S. G. Engelmann, and E. R. Wingrove. 2005. Facts, Values, and 'Real' Numbers. In George Steinmetz, ed., The Politics of Method in the Human Sciences: Positivism and Its Epistemological Others. Durham: Duke University Press, 470-95.

Mommsen, Wolfgang J. 1988. La situation de l'historien et l'enseignement de l'histoire dans la République Fédérale d'Allemagne. In René Réymond, ed., Etre historien aujourd'hui. Toulouse: Erés, 29-42.

Mommsen, Wolfgang J. 1991. German Historiography during the Weimar Republic and the Émigré Historians. In Andreas W. Daum, Hartmut Lehmann, and James J. Sheehan, eds., The Second Generation: Émigrés from Nazi Germany as Historians. New York: Berghahn, 33-67.

Muller, Jerry Z. 1987. The Other God that Failed: Hans Freyer and the Deradicalization of German Conservatism. Princeton: Princeton University Press.

Mullins, Nicholas C. 1973. Theories and Theory Groups in Contemporary American Sociology. New York: Harper \& Row.

Nicolas, Serge. 2007. Histoire de la philosophie en France au XIXe siècle. Paris: L'Harmattan.

Noiriel, Gérard. 1990. Naissance du métier d'historien. Genèses 1: 58-85.

Noiriel, Gérard. 1996. Sur la "crise" de l'histoire. Paris: Belin.

Novick, Peter. 1988. That Noble Dream: The "Objectivity Question" and the American Historical Profession. Cambridge: Cambridge University Press. 
Oakes, Guy. 1987. Weber and the Southwest German School: The Genesis of the Concept of the Historical Individual. In Theodor Mommsen and Jürgen Osterhammel, eds., Max Weber and His Contemporaries. London: Unwin Hyman, 434-46.

Oberkrome, Willi. 1993. Volksgeschichte: Methodische Innovation und völkische Ideologisierung in der deutschen Geschichtswissenschaft 1918-1945. Göttingen: Vandenhoeck \& Ruprecht.

Oberkrome, Willi. 1995. Aspekte der deutschsprachigen Volksgeschichte. In Michael Garleff, ed., Zwischen Konfrontation und Kompromiss. München: R. Oldenbourg, 37-46.

Peirce, Charles Sanders. 1931. Collected Papers, vol. 1. Cambridge: Harvard University Press.

Piriou, Odile. 2008. Que deviennent les diplômés de sociologie? Un état de la discipline et de son avenir. Socio-logos: Revue de l'association française de sociologie 3. At https://socio-logos.revues.org/1622 (consulted 2 Dec. 2016).

Raphael, Lutz. 1994. Die Erben von Bloch und Febvre: Annales-Geschichtsschreibung und nouvelle histoire in Frankreich 1945-1980. Stuttgart: Klett.

Rebérioux, Madeleine. 1983. Le débat de 1903: Historiens et sociologues. In Charles-Olivier Carbonell, ed., Au berceau des Annales: le milieu strasbourgeois. Toulouse: Presses de l'Institut d'études politiques de Toulouse, 219-30.

Revel, Jacques. 1979. Histoire et sciences sociales: les paradigmes des Annales. Annales. Histoire, Sciences Sociales 34, 6: 1360-76.

Revel, Jacques and Roger Chartier. 1979. Lucien Febvre et les sciences humaines. Historiens et geographes 272: 427-42.

Robbins, Derek. 2011. Social Theory and Politics: Aron, Bourdieu and Passeron, and the Events of May 1968. In S. Susen and B. S. Turner, eds., The Legacy of Pierre Bourdieu: Critical Essays. London: Anthem Press, 301-27.

Roche, Daniel. 1986. Les historiens aujourd'hui: Remarques pour un débat. Vingtième Siècle, revue d'histoire 12: 3-20.

Rössler, Beate. 2013. Kantian Autonomy and Its Social Preconditions. On Axel Honneth's Das Recht der Freiheit. Krisis: Journal for Contemporary Philosophy 1, $14-17$.

Rueschemeyer, Dietrich. 1958. Probleme der Wissenssoziologie. PhD diss., Cologne.

Salomon-Delatour, Gottfried. 1962. Sozialgeschichte und Geschichtssoziologie. In René König, ed., Handbuch der empirischen Sozialforschung. Stuttgart: F. Enke, 601-38.

Schieder, Wolfgang. 1987. Sozialgeschichte zwischen Soziologie und Geschichte: Das wissenschaftliche Lebenswerk Werner Conzes. Geschichte und Gesellschaft 13, 2: 244-66.

Schleier, Hans. 1975. Die bürgerliche deutsche Geschichtsschreibung der Weimarer Republik. Berlin: Akademie-Verlag.

Schmitt, Carl. 1950. Der Nomos der Erde im Völkerrecht des Jus publicum Europaeum. Köln: Greven.

Schnitzler, Sonja. 2012. Soziologie im Nationalsozialismus zwischen Wissenschaft und Politik. Wiesbaden: Springer VS.

Schulze, Winfried. 1974. Soziologie und Geschichtswissenschaft: Einführung in die Probleme der Kooperation beider Wissenschaften. München: W. Fink.

Schulze, Winfried. 1989. Deutsche Geschichtswissenschaft nach 1945. München: Oldenbourg.

Schützeichel, Rainer. 2004. Historische Soziologie. Bielefeld: Transcript.

Sewell, William H., Jr. 1996. Three Temporalities: Toward an Eventful Sociology. In Terrence J. McDonald, ed., The Historic Turn in the Human Sciences. Ann Arbor: University of Michigan Press, 245-80. 
Simiand, François. 1903. Méthode historique et science social. Revue de synthèse historique 6 (Jan.-June): 1-157.

Smith, Dennis. 1991. The Rise of Historical Sociology. Philadelphia: Temple University Press.

Steinmetz, George. 1998. Critical Realism and Historical Sociology. Comparative Studies in Society and History 40, 1, 170-86.

Steinmetz, George. 2005. American Sociology's Epistemological Unconscious and the Transition to Post-Fordism: The Case of Historical Sociology. In Julia Adams, Elisabeth S. Clemens, and Ann Shola Orloff, eds., Remaking Modernity: Politics, History, and Sociology. Durham: Duke University Press, 109-57.

Steinmetz, George. 2007a. The Devil's Handwriting: Precoloniality and the German Colonial State in Qingdao, Samoa, and Southwest Africa. Chicago: University of Chicago Press.

Steinmetz, George. 2007b. American Sociology before and after World War Two: The (Temporary) Settling of a Disciplinary Field. In Craig Calhoun, ed., Sociology in America: The ASA Centennial History. Chicago: University of Chicago Press, 314-66.

Steinmetz, George. 2009. Neo-Bourdieusian Theory and the Question of Scientific Autonomy: German Sociologists and Empire, 1890s-1940s. Political Power and Social Theory 20, 71-131.

Steinmetz, George. 2010a. Ideas in Exile: Refugees from Nazi Germany and the Failure to Transplant Historical Sociology into the United States. International Journal of Politics, Culture, and Society 23, 1: 1-27.

Steinmetz, George. 2010b. Charles Tilly, Historicism, and the Critical Realist Philosophy of Science. American Sociologist 41, 4: 312-36.

Steinmetz, George. 2011. Bourdieu, Historicity, and Historical Sociology. Cultural Sociology 11, 1: 45-66.

Steinmetz, George. 2013. Toward Socioanalysis: The 'Traumatic Kernel' of Psychoanalysis and Neo-Bourdieusian Theory. In Phil Gorski, ed., Bourdieu and Historical Analysis. Durham: Duke University Press: 108-30.

Steinmetz, George. 2015. Historical Sociology, Ethics, Policy, and Politics. Trajectories: Newsletter of the ASA Comparative and Historical Sociology Section 28, 2: 1-10.

Steinmetz, George. 2016. Social Fields, Subfields, and Social Spaces, at the Scale of Empires: Explaining the Colonial State and Colonial Sociology. Sociological Review 64, 2: 98-123.

Steinmetz, George. 2017. Sociology and Colonialism in the British and French Empires, 1940s-1960s. Journal of Modern History (forthcoming in Sept.).

Stelzel, Philipp. 2010. Rethinking Modern German History: Critical Social History as a Transatlantic Enterprise, 1945-1989. PhD diss., University of North Carolina-Chapel Hill.

Taylor, Peter J. 2016. Corporate Social Science and the Loss of Curiosity. Items: Insights from the Social Sciences. Social Science Research Council, New York. At http:// items.ssrc.org/corporate-social-science-and-the-loss-of-curiosity/ (accessed 2 Dec. 2016).

Tenbruck, Friedrich H. 1984. Die unbewältigten Sozialwissenschaften. Graz: Verlag Styria.

Tendler, Joseph. 2013. Opponents of the Annales School. New York: Palgrave Macmillan.

Troeltsch, Ernst. 1922. Der Historismus und seine Probleme. Tübingen: C. B. Mohr.

Trüper, Henning. 2005. Die Vierteljahrschrift für Sozial- und Wirtschaftsgeschichte und ihr Herausgeber Hermann Aubin im Nationalsozialismus. Stuttgart: Steiner. 
Vom Brocke, Bernhard. 1971. Kurt Breysig: Geschichtswissenschaft zwischen Historismus und Soziologie. Lübeck: Matthiesen.

Von Wiese, Leopold. 1948. Erster Vortrag. Die gegenwärtige Situation, soziologisch betrachtet. In Verhandlungen des Achten Deutschen Soziologentages. Tübingen: Verlag J.C.B. Mohr, 20-41.

Wahl, Adalbert. 1925-1926. Wiederholungen im Verlauf des historischen Geschehens. Philosophischer Anzeiger 1: 417-26.

Wang, Yingyao. 2016. Homology and Isomorphism: Bourdieu in Conversation with New Institutionalism. British Journal of Sociology 67, 2: 348-70.

Wehler, Hans-Ulrich, ed. 1968. Moderne deutsche Sozialgeschichte. Köln: Kiepenheur \& Witsch.

Wehler, Hans-Ulrich. 1971-1982. Deutsche Historiker, vols. 1-9. Göttingen: Vandenhoeck \& Ruprecht.

Wehler, Hans-Ulrich. 1972. Geschichte und Soziologie. Köln: Kiepenheuer \& Witsch.

Wehler, Hans-Ulrich. 1975. Modernisierungstheorie und Geschichte. Göttingen: Vandenhoeck und Ruprecht.

Wehler, Hans-Ulrich 1977. Sozialgeschichte. Göttingen: Vandenhoeck und Ruprecht.

Wehler, Hans-Ulrich. 1984. Historiography in Germany Today. In Jürgen Habermas, ed., Observations on "The Spiritual Situation of the Age." Cambridge: MIT Press, 221-59.

Weiß, Johannes. 1995. Negative Soziologie. Ethik und Sozialwissenschajften 6: 241-46.

Welskopp, Thomas. 2005. Alien Allies: The Relations between History, Sociology, and Economics in Germany, 19th-20th Centuries. In Ignacio Olábarri and Francisco Caspistegui, eds., The Strength of History at the Doors of the New Millenium. Pamplona: Ediciones Universidad de Navarra, 103-28.

Welskopp, Thomas. 2010. Irritating Flirtations: Reflections on the Relationship between History and Sociology since the 1970s. InterDisciplines 1: 9-42.

Whimster, Sam. 1987. Karl Lamprecht and Max Weber. In Theodor Mommsen and Jürgen Osterhammel, eds., Max Weber and His Contemporaries. London: Unwin Hyman, 268-83.

Wilson, Edward O. 1998. Consilience: The Unity of Knowledge. New York: Knopf.

Wittebur, Klemens. 1991. Die Deutsche Soziologie im Exil, 1933-1945: Eine Biographische Karthographie. Münster: Lit.E

Wright, Erik Olin. 2012. Transforming Capitalism through Real Utopias. American Sociological Review 20, 10: 1-25.

Ziebura, Gilbert. 1990. Die Rolle der Sozialwissenschaften in der westdeutschen Historiographie der internationalen Beziehungen. Geschichte und Gesellschaft 16, 1: 79-103.

Zysiak, Agata. 2015. Modernizing Science: Between a Liberal, Social, and Socialistic University - The Case of Poland and the University Of Łódź (1945-1953). Science in Context 28, 2: 215-36. 
Abstract: This article develops a theory of interdisciplinarity and examines relations between historians and sociologists in Germany and France over the course of the twentieth century, focusing in on several key moments of interdisciplinary activity. Interdisciplinary engagements are motivated by scholarly problems, field-specific interests and battles, and pressures and inducements coming from states, businesses, and scientific institutions. Analysis of the most productive moments of cross-disciplinary interaction suggests that they occur when disciplines are equal in power and when scholars are motivated by scholarly problems and disciplinary conflicts to move beyond their disciplines. More generative forms of interdisciplinarity are dialogic and processual, characterized by a fusion of perspectives; less productive forms are externally induced, involve asymmetrical partners, and are organized around division of disciplinary labor rather than an interpenetration of perspectives. The most productive interdisciplinary conjunctures result from serendipitous resonances and contingent synchronicities between subfields of semi-autonomous disciplines. It is thus impossible to produce the most fruitful forms of interdisciplinarity deliberately. The article examines three cases of symmetrical, processual interdisciplinarity involving sociology and history. Two of these cases were located in the French academic field, first between the wars, and then again after 1980. The other case of dialogic collaboration between historians and sociologists begins in Nazi Germany and continues after 1945 into the 1960s, leading to the formation of West German Historische Sozialwissenschaft. Examples of unbalanced interdisciplinarity include German "History-Sociology" during the Weimar Republic, in which sociologists' opening to history was not reciprocated by professional historians and Historische Sozialwissenschaft after 1970.

Key words: Social Fields, Field Theory, Pierre Bourdieu, interdisciplinarity, Historical Sociology, Social History, German historians - twentieth century, French historians - twentieth century, French social science, German social science 